\title{
Validitas Instrumen Penilaian Kemampuan Berpikir Tingkat Tinggi tentang Materi Tumbuhan untuk Peserta Didik SMA/MA Kelas X
}

\author{
Lastri Maisari $^{1}$, Rahmawati $D^{2}$, Des $\mathbf{M}^{3}$, Sa'diatul Fuadiyah ${ }^{4}$ \\ 1,2,3,4) Program Studi Pendidikan Biologi, Jurusan Biologi, FMIPA, Universitas Negeri Padang Jalan Prof. Dr. Hamka \\ Kampus Air Tawar Padang, Sumatera Barat, Indonesia
}

Pengiriman: Januari 2020; Diterima: Juli 2020; Publikasi: Juli 2020

\begin{abstract}
Assessment in the 2013 curriculum places more emphasis on cognitive assessment possessed by students. Assessment instruments made by teachers at daily tests are generally still at the $\mathrm{C} 1-\mathrm{C} 3$ cognitive level, instruments that can be used to train students' abilities are at the C4-C6 level. This study aims to produce instruments for assessing higher order thinking skills on Plant material for high, reliable, high school/MA grade X students, difficulty levels, distinguishing features and good quality options. This study uses 4-D models. Which consists of the stages define, design, develop and disseminate. The disseminate stage was not carried out. The subjects of this research were 34 students of SMAN 7 Padang. The validity test results show logically valid questions with an average value of 3.27 with valid criteria. The average practicality value of $98.61 \%$ with very practical question criteria, the reliability of the questions is 0.85 , and the level of difficulty of the questions between 0.29 to 0.67 with moderate criteria, as well as the questions have a good difference in power and good quality of question options. From the research it can be concluded that an instrument of assessment of high-level thinking ability about Plant material for highschool/MA grade X students has been produced which is valid, reliable, has a moderate level of difficulty, good differentiation and good quality options.
\end{abstract}

Kyword: Assessment Instruments, Higher Level Thinking Ability, Plant Material

\begin{abstract}
ABSTRAK. Penilaian dalam kurikulum 2013 lebih menekankan kepada penilaian kognitif yang dimiliki peserta didik. Instrumen penilaian yang dibuat oleh guru pada ulangan harian umumnya masih berada pada tingkatan kognitif $\mathrm{C} 1-\mathrm{C} 3$, instrumen yang dapat digunakan untuk melatih kemampuan peserta didik berada pada tingkatan C4-C6. Penelitian ini bertujuan untuk menghasilkan instrumen penilaian kemampuan berpikir tingkat tinggi pada materi Tumbuhan untuk peserta didik SMA/MA Kelas X yang valid, reliabel, tingkat kesukaran sedang, daya pembeda dan kualitas option yang baik. Penelitian ini menggunakan model yaitu 4$\mathrm{D}$ models. Yang terdiri dari tahap define, design, develop dan disseminate. Tahap dessiminate itu tidak dilakukan. Subjek penelitian ini yaitu 34 orang siswa SMAN 7 Padang. Hasil uji validitas menunjukkan soal valid secara logis dengan rata-rata nilai yaitu 3,27 dengan kriteria valid. Nilai rata-ra praktikalitas 98,61\% dengan kriteria soal sangat praktis, reliabilitas soal yaitu 0,85 , serta tingkat kesukaran soal antara 0,29 sampai 0,67 dengan kriteria sedang, serta soal memiliki daya beda yang baik dan kualitas option soal yang baik. Dari penelitian dapat disimpulkan telah dihasilkan instrumen penilaian kemampuan berpikir tingkat tinggi tentang materi Tumbuhan untuk peserta didik SMA/MA kelas $\mathrm{X}$ yang valid, reliabel, tingkat kesukaran sedang, daya pembeda yang baik dan kualitas option yang baik.
\end{abstract}

Kata kunci: Instrumen Penilaian, Kemampuan Berpikir Tingkat Tinggi, Materi Tumbuhan

*Penulis Korespondensi:

Alamat surel: lastrimaisari98@gmail.com 


\section{PENDAHULUAN}

Pendidikan merupakan suatu bentuk kegiatan manusia dalam kehidupannya dan menempatkan suatu tujuan sebagai bentuk yang ingin dicapai, baik tujuan yang dirumuskan bersifat secara abstrak maupun yang di rumuskan secara khusus untuk memudahkan pencapaian tujuan yang lebih tinggi (Hasbullah, 2009: 10).

Salah satu aspek yang sangat berpengar-uh terhadap keberhasilan Pendidikan Nasional adalah Kurikulum. Kurikulum merupakan suatu perangkat rencana dan pengaturan mengenai tujuan, isi dan bahan pembelajaran serta cara yang digunakan sebagai pedoman dalam penyelenggaraan kegiatan pembelajaran agar tercapainya tujuan pembelajaran tersebut (BSNP, 2006). Menurut Kunandar (2015: 34) tujuan pendidikan dalam kurikulum untuk membangun masa kini dan masa depan yang akan datang yang dapat menjadi lebih baik dengan berbagai kemampuan intelektual, komunikasi, sikap sosial, peduli dan berpartisipasi untuk membangun kehidupan yang lebih baik lagi.

Kurikulum 2013 menuntut peserta didik untuk lebih aktif dan mampu berpikir kritis serta mampu berpikir secara logis. Menurut Setiadi (2016: 167) Kurikulum 2013 menekankan pada proses pendidikan yang menyeluruh sehingga dapat menyentuh cakupan yang lebih luas yaitu ranah kognitif, afektif, dan psikomotor. Karakteristik dalam kurikulum 2013 mengutamakan pada jenjang pendidikan dasar hingga menengah dan menekankan pada pendekatan saintifik.

Proses pencapaian pembelajaran peserta didik dapat diukur dengan melakukan penilaian.
Penilaian dilakukan dengan tujuan untuk mengetahui apakah peserta didik tersebut memahami pembelajaran, dan juga memperbaiki program pembelajaran. Menurut Sani (2016: 15) mengungkapkan bahwa pada umumnya, guru melakukan penilaian di kelas terkait dengan kegiatan belajar mengajar dalam upaya menghimpun sebuah data, fakta, serta dokumen belajar peserta didik yang bertujuan untuk melakukan perbaikan program pembelajaran.

Penilaian yang dilakukan dalam proses pembelajaran untuk mengetahui tingkat kemampuan peserta didik dalam memahami materi yang telah disampaikan. Menurut Sudjana (2009: 22) penilaian merupakan upaya atau sebuah tindakan untuk mengetahui sejauh mana tujuan yang telah di tetapkan itu tercapai atau tidak.

Hasil dari penilaian dapat memberikan motivasi kepada peserta didik untuk lebih baik lagi. Proses pelaksanaan penilaian, guru sangat memerlukan instrumen penilaian dalam bentuk soal-soal baik untuk menguji kemampuan kognitif, afektif maupun psikomotor peserta didik (Budiman, 2014). Penilaian aspek kognitif mengarah kepada penilaian pengetahuan yang dimiliki peserta didik. Instrumen yang digunakan untuk menilai kemampuan kognitif adalah dengan menggunakan tes (Anwar, 2009: 30). Instrumen yang baik adalah instrumen yang valid, reliabel, objektif, praktis dan mudah dilaksanakan (Yusuf, 2015: 58-60).

Kemampuan berpikir tingkat tinggi (High Order Thingking Skill-HOTS) merupakan suatu penggunaan pikiran yang memiliki cakupan secara lebih luas untuk menemukan suatu tantangan baru. 
Kemampuan berpikir tingkat tinggi ini mengharapkan seseorang untuk menerapkan informasi baru atau pengetahuan sebelumnya untuk menemukan jawaban dalam situasi baru (Rofiah, 2013: 17).

Salah satu studi internasional yang mengukur kemampuan kognitif siswa yaitu Trends in Internasional Mathematics and Science Study (TIMSS) dan Program for Internasional Student Assessment (PISA), merupakan studi yang dilakukan untuk mengukur kemampuan berpikir tingkat tinggi peserta didik yang dilakukan 4 tahun sekali. Indonesia merupakan salah satu yang mengikuti PISA.

Pemahaman, penalaran, dan penerapan merupakan aspek yang diterapkan TIMSS untuk menunjukkan kemampuan berpikir peserta didik. PISA merupakan suatu sistem ujian yang diselenggarakan oleh Organisation for Economic Cooperation and Development (OECD), tujuan utamanya untuk mengevaluasi sistem pendidikan diseluruh dunia. Peserta didik yang dipilih secara acak untuk mengikuti tes, peserta didik yang dipilih adalah peserta didik yang berusia 15 tahun (Kemendikbud: 2016).

Berdasarkan hasil wawancara salah seorang guru mata pelajaran Biologi di SMAN 7 Padang, yaitu Ibu Ratnawita, S.Pd, pada tanggal 25 Maret 2019 diketahui bahwa guru selalu memberikan evaluasi setelah proses pembelajaran pada setiap selesai KD. Evaluasi yang diberikan dalam bentuk Penilaian Harian. Pelaksanaan dalam melakukan penilaian harian guru hanya menerapkan kemampuan berpikir tingkat tinggi (Higer Order Thingking Skill- HOTS) dengan tingkatan kognitif C4-C6 pada beberapa soal tertentu. analisis terhadap soal ujian tengah semester ganjil yang digunakan merupakan hasil dari Musyawarah Guru Mata Pelajaran (MGMP) kota Padang. Analisis tingkat kognitif dari soal tengah semester ganjil yang didapatkan yaitu, soal $\mathrm{C} 1=32 \%$, soal $\mathrm{C} 2=36 \%$ dan soal $\mathrm{C} 3=32 \%$.

Berdasarkan hasil wawancara juga mengungkapkan bahwa guru masih mempertimbangkan kemampuan siswa untuk menjawab soal-soal tingkat tinggi mengingat kemampuan siswa yang bersifat heterogen, serta belum adanya penerapan pembelajaran berpikir tingkat tinggi di sekolah. Menurut Hidayati (2017: 147) berpikir tingkat tinggi merupakan proses keterampilan berpikir secara mendalam, Ada dua bentuk evaluasi yang diberikan yaitu objektif dan essay.

Peneliti melakukan uji kemampuan awal untuk melihat kemampuan berpikir tingkat tinggi peserta didik SMAN 7 Padang kelas X IPA 3 sebanyak 23 orang peserta didik pada tanggal 25 Maret 2019. Uji coba menggunkan 32 item soal pilihan ganda berupa soal kemampuan berpikir tingkat tinggi pada materi yang telah dipelajari peserta didik yaitu Protista. Soal yang digunakan yaitu soal yang telah dikembankan Rahmadhani (2018), soal tersebut telah valid, praktis serta memiliki kuliatas item yang baik. Dari uji coba soal didapatkan rata-rata nilai peserta didik bekisar 43,75. Selain melakukan wawancara dengan guru mata pelajaran, uji coba soal, observasi juga dilakukan dengan penyebaran angket pada peserta didik X MIPA 3 SMAN 7 Padang. Hasil penyebaran angket didapatkan bahwa soal yang diker-jakan peserta didik bersifat hafalan sehingga dalam mempersiapkan ujian siswa sering 
menghafal materi yang akan diujikan tanpa adanya pemahaman dari materi tersebut.

\section{METODE PENELITIAN}

Penelitian ini merupakan penelitian pengembangan (Developmental Research). Penelitian ini dilakukan di Fakultas Matematika dan Ilmu Pengetahuan Alam (FMIPA) Universitas Negeri Padang (UNP) dan SMAN 7 Padang. Subjek dari penelitian ini terdiri dari validator dan peserta didik. Validator terdiri dari 2 orang dosen Jurusan Biologi UNP. Subjek penelitian ini terdiri dari 34 orang peserta didik kelas X SMAN 7 Padang.

Data penelitian ini berupa data dari hasil validasi, uji praktikalitas, reliabilitas, tingkat kesukaran, dan daya pembeda, alternatif jawaban merupakan pengecoh soal dalam pilihan ganda. Tes yang diberikan merupakan tes tertulis bentuk pilihan ganda biasa, pilihan ganda sebab dan akibat dan pilihan ganda asosiasi. Dokumentasi diperoleh berupa lembar jawaban siswa dan foto pelaksanaan penelitian. Serta nantinya melakukan uji validitas yang dilakukan Dosen dan uji praktikalitas yang dilakukan guru. Data yang diperoleh dalam penelitian ini dianalisis.

\section{HASIL DAN PEMBAHASAN}

\section{A. Hasil Penelitian}

1. Pendefinisian (define)

a. Hasil Analisis Masalah

Pada tahap ini peneiliti melakukan wawancara dengan salah satu guru Biologi di SMAN 7 Padang. Wawancara dilakukan bertujuan untuk mengetahui proses pembelajaran dalam permasalahan instrumen yang digunakan di sekolah. Kurikulum 2013 intumen penilaian yang dituntut adalah instrumen yang dapat melatih peserta didik untuk berpikir tingkat tinggi. Penulis melakukan analisis pada tingkatan kognitif terhadap ujian UTS, berdasarkan analisis tersebut soal yang diujikan masih dominan berada pada tingkat kognitif memahami (C1) yaitu sebayak $25 \%$, tingkat kognitif mengingat (C2) yaitu 50\%, dan tingkat kognitif mengaplikasikan (C3) yaitu $30 \%$. Hal ini disebabkan karena guru masih mempertimbangkan kemampuan peserta didik yang masih heterogen.

\section{b. Hasil Analisis Peserta Didik}

Berdasarkan hasil observasi di SMA N 7 Padang pada tanggal 20 maret 2019, diketahui umur peserta didik kelas $\mathrm{X}$ adalah 15-17 tahun, sehingga dianggap telah mampu untuk berpikir tingkat tinggi. Uji coba soal dilakukan kepada peserta didik utuk melihat kemampuan peserta didik, soal yang di uji cobakan yaitu soal yang telah valid yang dilakukan oleh Putri (2017) pada materi virus didapatkan rata-rata nilai peserta didik yaitu 31,2. Berdasarkan hasil uji coba dikatakan bahwa kemampuan berpikir tingkat tinggi peserta didik masih redah. Masalah ini terjadi karena peserta didik belum terbiasa mengerjakan soal yang menuntut peserta didik untuk berpikir tingkat tinggi seperti soal ujian yang telah diberikan guru.

c. Hasil Analisis Kurikulum

Analisis kurikulum difokuskan pada Kompetensi Inti (KI) dan Kompetensi Dasar (KD) untuk materi Tumbuhan yang kemudian dijabarkan menjadi indikator. Kompetensi Dasar (KD) harus sesuai dengan kurikulum yang ada pada saat sekarang ini yaitu kurikulum 2013 (revisi 2016) pada Permendikbud tahun 2016 nomor 24. 
Berdasarkan kriteria minimal tingkat-an kognitif yang diminta untuk mampu berpikir tingkat tinggi yaitu menganalisis (C4), mengevalusi (C5), dan mencipta (C6). Berdasar-kan analisis terhadap KD yang telah dilakukan selanjutnya merumuskan indikator pencapaian kompetensi berdasarkan tingkatan kognitif yang berlaku. Dirumuskan sembilan indikator pencapaian kompetensi berdasarkan KD 3.7 yaitu pada materi Tumbuhan.

d. Hasi analisis konsep

Analisis konsep dilakukan dengan mengidentifikasi konsep-konsep utama dari materi tumbuhan. Konsep utama pada materi tumbuhan terkait dengan indikator pencapaian kompetensi yaitu megenai ciri-ciri, cara hidup, dan mengaitkan perananya dalam kehidupan. Konsep ini merupakan konsep yang harus dikuasai oleh peserta didik untuk mengerjakan instrumen penilaian kemampuan berpikir tingkat tinggi. Analisis ini mengacu kepada materi pokok pada silabus mata pelajaran biologi kurikulum 2013 revisi 2016.

\section{Perancangan (design)}

Pada tahap perancangan intrumen penilaian kemampuan berpikir tingkat tinggi dihasilkan kerangka tampilan. Hal yang dilakukan pada tahap ini yaitu: pemilihan aplikasi, pemilihan format dan perancangan awal instrumen penilaian.
a. Pemilihan aplikasi
b. Pemilihan format
c. Perancangan awal
3. Pengembangan (develop)

Pada tahap pengembangan (develop) dalam penelitian ini meliputi validitas logis, praktikalitas, dan analisis butir soal yang meliputi validitas empiris, reliabilitas, tingkat kesukaran, daya pembeda, dan kualitas option yang baik.

a. Validitas logis

Validitas merupakan suatu tes yang menentukan sejauh mana tes mengukur apa yang seharusnya diukur. Validitas logis pada instrumen penilaian kemampuan berpikir tingkat tinggi ini dilakukan oleh dua orang validator yang terdiri dari dosen Jurusan Biologi FMIPA UNP dangan menggunakan angket validasi. Selama proses validasi berlangsung terdapat beberapa saran dari validator yang dpat dijadikan pertimbangan dalam memperbaiki instrumen penilaian kemampuan berpikir tingkat tinggi pada materi Tumbuhan. Berdasarkan Tabel 1 dibawah ini.

\begin{tabular}{ccc}
\hline Aspek & $\begin{array}{c}\text { Rata-rata } \\
\text { Nilai } \\
\text { Validitas }\end{array}$ & Kriteria \\
\hline Materi & 0,84 & Valid \\
Kostruksi & 0,81 & Valid \\
Bahasa & 0,87 & Valid \\
Barpikir & 0,85 & Valid \\
Tingkat Tinggi & & \\
\hline Rata-rata & 3,37 & Valid \\
\hline
\end{tabular}

b. Validitas empiris instrumen penilaian kemampuan berpikir tingkat tinggi

Validitas empiris bertujuan untuk menentukan kelayakan soal, menurut (Arikunto, 2012: 81) butiran soal instrumen dapat dikata-kan memiliki validitas empiris yang baik jika hasil yang diharapkan sesuai dengan pengalam-an. Pengalaman yang dimaksud adalah penga-laman yang sudah diukur berdasarkan uji coba yang telah dilakukan. Berdasarkan Tabel 2 dibawah ini 


\begin{tabular}{|c|c|c|}
\hline \multirow{2}{*}{$\begin{array}{c}\text { Nomor } \\
\text { soal }\end{array}$} & \multicolumn{2}{|c|}{ Validitas } \\
\hline & $\mathbf{R x y}$ & Kriteria \\
\hline 1. & 0.421 & Valid \\
\hline 2. & 0.538 & Valid \\
\hline 3. & 0.644 & Valid \\
\hline 4. & 0.452 & Valid \\
\hline 5. & 0.427 & Valid \\
\hline 6. & 0.398 & Valid \\
\hline 7. & 0.290 & Valid \\
\hline 8. & 0.446 & Valid \\
\hline 9. & 0.516 & Valid \\
\hline 10. & 0.346 & Valid \\
\hline 11. & 0.409 & Valid \\
\hline 12. & 0.443 & Valid \\
\hline 13. & 0.152 & - \\
\hline 14. & 0.405 & Valid \\
\hline 15. & 0.450 & Valid \\
\hline 16. & 0.110 & - \\
\hline 17. & 0.583 & Valid \\
\hline 18. & 0.406 & Valid \\
\hline 19. & 0.159 & - \\
\hline 20. & 0.349 & Valid \\
\hline 21. & 0.320 & Valid \\
\hline 22. & 0.206 & - \\
\hline 23. & 0.295 & Valid \\
\hline 24. & 0.279 & Valid \\
\hline 25. & 0.212 & - \\
\hline 26. & 0.268 & - \\
\hline 27. & 0.313 & Valid \\
\hline 28. & 0.256 & - \\
\hline 29. & 0.311 & Valid \\
\hline 30. & 0.227 & - \\
\hline 31. & 0.219 & - \\
\hline 32. & 0.328 & Valid \\
\hline 33. & 0.308 & Valid \\
\hline 34. & 0.163 & - \\
\hline 35. & 0.283 & Valid \\
\hline 36. & 0.313 & Valid \\
\hline 37. & 0.041 & - \\
\hline 38. & 0.230 & - \\
\hline 39. & 0.114 & - \\
\hline 40. & 0.256 & - \\
\hline 41. & 0.433 & Valid \\
\hline 42. & 0.379 & Valid \\
\hline 43. & 0.074 & - \\
\hline 44. & 0.187 & - \\
\hline 45. & 0.455 & Valid \\
\hline
\end{tabular}

\begin{tabular}{|ccc|}
\hline Nomor & \multicolumn{2}{c|}{ Validitas } \\
\cline { 2 - 3 } soal & Rxy & Kriteria \\
\hline 46. & 0.358 & Valid \\
\hline 47. & 0.349 & Valid \\
\hline 48. & 0.260 & - \\
\hline 49. & 0.438 & Valid \\
\hline 50. & 0.383 & Valid \\
\hline
\end{tabular}

Data yang didapatkan berdasarkan hasil uji coba soal didapatkan 33 soal yang dapat dikatakan valid dan 17 soal tidak valid berdasarkan validitas empirisnya

\section{B. Pembahasan}

Pengembangan instrumen penilaian berbasis HOTS untuk pembelajaran teks deskripsi perlu dilakukan agar penilaian yang dilakukan pendidik sesuai dengan kurikulum 2013. Selain itu, dapat melatih dan meningkatkan kemampuan berpikir tingkat tinggi peserta didik terhadap materi dan informasi yang tedapat pada teks deskripsi sebagai upaya peningkatan kualitas pembelajaran (Dhini, 2019).

Instrumen penilaian kemampuan berpikir tingkat tinggi yang dikembangkan sudah valid berdasarkan empat aspek yang telah dilakukan validasi oleh validator, yaitu pada aspek materi, konstruksi, bahasa, dan kemampuan berpikir tingkat tinggi. Data validitas logis didapatkan dari 2 orang validator. Aspek materi didapatkan ratarata nilai validitas dari kedua validator sebesar 0,84 dengan kategori valid. Dapat disimpulkan bahwa materi yang digunakan dalam instrumen penilaian dapat digunakan untuk mengembangkan kemampuan berpikir tingkat tinggi peserta didik sesuai dengan Kompetensi Dasar pada kurikulum 2013. Depdiknas (2008: 8) menyatakan bahwa materi dalam mengembangkan suatu materi pengajaran materi tersebut harus sesuai dengan 
dengan tuntutan Kompetensi Dasar dan Indikator Pencapaian Kompetensi.

Setelah dilihat dari aspek materi, dapat dilihat dari aspek konstruksi instrumen penilaian kemampuan berpikir tingkat tinggi yang telah valid dengan rata-rata 0,81 yang telah mencapai kategori valid. Konstruksi soal berhubungan dengan rumusan soal yang diberikan jelas dan berkaitan dengan materi yang dinyatakan, pokok soal dan dan pilihan jawaban merupakan pernyataan yang diperlukan saja, pokok soal tidak memberikan petunjuk kunci jawaban soal.

Dilihat dri aspek bahasa/budaya instrumen penilaian kemampuan berpikir tingkat tinggi yang dikembangkan didapatkan 0,87 yang telah mencapai kriteria valid. Jika dilihat dari aspek segi bahasa sudah baik, sesuai dengan Kaidah Bahasa Indonesia yang baik dan benar, mudah dipahami peserta didik, dan rumusan kalimat ,pada soal tidak menimbulkan penafsiran ganda. Sani (2014: 223) menyatakan bahwa pada soal harus menggunakan bahasa yang sesuai dengan kaidah Bahasa Indonesia yang baik.

Dari segi berpikir tingkat tinggi dapat dilihat instrumen soal sudah valid dengan rata-rata nilai validasi 0,85 yang sudah mencakup kriteria valid. Hal ini menunjukan bahwa instrumen penilaian kemampuan berpikir tingkat tinggi sudah mengukur tingkatan kognitif peserta didik yang meliputi tingkatan menganalisis, mengevaluasi, dan mencipta.

Secara keseluruhan aspek, instrumen penilaian kemampuan berpikir tingkat tinggi peserta didik didapatkan rata-rata validitas logisnya yaitu 0,84 dengan kategori valid. Berdasarkan dari hasil tersebut instrumen penilaian kemampuan berpikir tingkat tinggi pada materi Tumbuhan yang berupa soal pilihan ganda biasa, pilihan ganda sebab-akibat, dan pilihan ganda asosiasi yang memiliki kriteria valid berdasarkan validitas logisnya. Dapat dikatakan bahwa instrumen penilaian kemampuan berpikir tingkat tinggi dapat digunakan dalam penilaian biologi. Sebelum menggunakan harus diuji praktikalitas dan validitas empiris, agar instrumen yang dikembangkan praktis dan valid.

\section{KESIMPULAN DAN SARAN}

\section{A. Kesimpulan}

Berdasarkan penelitian yang telah dilakukan, dapat disimpulkan bahwa telah dihasilkan instrumen penilaian kemampuan berpikir tingkat tinggi pada materi tumbuhan yang valid secara logis dan empiris, praktis, reliabel, tingkat kesukaran sedang, daya pembeda yang baik, dan distraktor (pengecoh) yang baik.

\section{B. Saran}

Berdasarkan penelitian yang telah dilakukan, maka peneliti menyarankan

1. Instrumen penilaian kemampuan berpikir tingkat tinggi yang telah dikembangkan dapat mengukur dan meningkatkan kemampuan berpikir tingkat tinggi peserta didik.

2. Uji coba pada instrumen penilaian kemampuan berpikir tingkat tinggi sebaiknya dilakukan setelah peserta didik selesai mempelajari materi yang akan diujikan untuk mendapatkan hasil yang maksimal

\section{DAFTAR PUSTAKA}

Ambiyar. 2012. Pengukuran dan Tes Dalam Pendidikan. Padang: UNP Pres. 
Amirono dan Daryanto. 2016. Evaluasi dan Penilaian Pembelajaran Kurikulum 2013. Yogyakarta: Gava Media.

Arikunto, S. 2013. Dasar-Dasar Evaluasi Pendidikan. Jakarta: Bumi Aksara.

Arifin, Z. 2012. Evaluasi Pembelajaran: Prinsip, Teknik, Prosedur. Bandung: Remaja Rosdakarya.

Budiman, A. dan Jailani. 2014. Pengembangan Instrumen Asesmen Higher Order Thingking Skills (HOTS) pada Materi Mata Pelajaran Matematika SMP Kelas VIII Semester 1. Jurnal Riset Pendidikan Matematika. Vol. 1 No. 2, 139-151.

Depdiknas. 2008. Sistem Pendidikan Nasional. Jakarta: Departemen Pendidikan Nasional.

Daryanto. 2014. Evaluasi Pendidikan. Jakarta: Reneka Cipta.

Heong. 2011. The Level of Marzano Higher Order Thinking Skills among Technical Education Students.

Julianingsish, suhaesti. 2017. Pengembangan Asesmen Higher Order Thingking Skill (HOTS) untuk Mengukur Dimensi Pengetahuan IPA di SMP. Universitas Negeri Lampung

Kunandar. 2015. Penilaian Autentik (Penilaian Hasil Belajar Peserta Didik Berdasarkan Kurikulum 2013). Jakarta: Raja Grafindo persada.

Mustikasari, Vita Ria, Muzil dan Lia Puji Lestari. 2018. Pengembang Instrumen Penilaian Kemampuan Berpikir Tingkat Tinggi Materi Sistem Pendengaran dan Sonar SMP. Jurnal Eksakta Pendidikan. ISSN: 2614-1221. Malang: FMIPA Universitas Negeri Malang.

Nofiana, Mufida., Sajidan., dan Punguh. 2016. "Pengembangan Instrumen Evaluasi Higher Order Thinking Skill pada Materi Plantae".

Permendiknas. 2007. Permendiknas Nomor 16 Tahun 2007 tentang Standar Kualifikasi Akademik dan Kompetensi
Guru Mata Pelajaran. Jakarta: Balitbang.

Rahmadhani. R. 2018. Analisis Aspek Kemampuan Berpikir Tingkat Tinggi Pada Instrumen Penilaian Materi Protista Untuk Peserta Didik SMA/MA Kelas X. Jurnal BIODIK Vol.4, No. 1:8-17.

Rofiah, E., N. S. Aminah, dan E. Y. Ekawati. 2013. "Penyusunan Instrumen Tes Kemampuan Berpikir Tingkat Tinggi Fisika Pada Siswa SMP". Jurnal Pendidikan Fisika, Vol. 1No. 2, 17-22.

Safitri. R. 2017. Pengembangan Instrumen Penilaian Kemampuan Berpikir Tingkat Tinggi pada Materi Virus untuk Peserta Didik SMA/MA Kelas X. Skripsi, 62 Hal. Universitas Negeri Padang, Padang, Indonesia, September 2017.

Sani, R. A. 2016. Penilaian Autentik . jakarta: Bumi Aksara.

Setiadi, Hari. 2016. "Pelaksanaan Penilaian pada Kurikulum 2013”. Jurnal Penelitian dan Evaluasi Pendidikan. Vol. 20 No. 2, 166-178.

Sudjana, Nana. 2008. Penilaian Hasil Proses Belajar Mengajar. Bandung: Remaja Rosdakarya Offset.

Sudijono, A. 2012. Pengantar Evaluasi Pendidikan. Jakarta: Rajawali Press.

Sukardi. 2012. Evaluasi Pendidikan: prinsip dan operasionalnya. Jakarta: Bumi Aksara.

Sunarti dan Rahmawati, Selly. 2014. Penilaian dalam Kurikulum 2013: Membantu Guru dan Calon Mengetahui Langkahlangkah Penilaian Pembelajaran. Yogyakarta: ANDI Offset.

Uno, H.B. dan Koni S. 2012. Asesmen Pembelajaran. Jakarta: Bumi Aksara.

Yusuf, M. 2015. Asesmen dan Evaluasi Pendidikan: Pilar Penyedia Informasi dan Kegiatan Pengendalian Mutu Pendidikan. Jakarta: Prenadamedia Grup. 